\title{
The Infant Jesus as Divine Love: a Dressed Sculpture from Évora's Museum
}

\author{
Diana Rafaela Pereira \\ Universidade do Porto \\ dianarafaelapereira@gmail.com
}

The «Infant Jesus as Divine Love» is a noteworthy example of the exuberance reached by dressed sculptures of the Holy Child in Portugal [1]. The provenance of this $18^{\text {th }}$ century sculpture is unknown ${ }^{1}$. It may have belonged to a religious institution, before being integrated in the Public Library collection. Finally, in 1915, it was incorporated in Évora's National Museum.

It is a lead sculpture, painted with very realistic flesh tones, in consonance with an elegant shape proper of a classical and erudite workmanship. In this unusual representation the Infant is holding a silver bow, arrows and a quiver, personifying Divine Love. In the left hand he holds a flower bouquet made of silk and paper.

The right hand gesture, without the bow, is current in other sculptures, and is usually interpreted as a blessing. Therefore, the present iconography may differ from the initial intention and be the result of a later adaptation.

When faced with these less common sculptures of the Infant as Divine Love, we recurrently see them identified as «the Infant as Cupid», and explained by the popular practice of dressing the Child with profane clothing, the lack of religious education of the cloistered nuns, and their extravagant wishes (Gonçalves, 1967: 18-19; Fortuna, 1982: 328). But these seem to be, in fact, the result of the widespread publications about the Divine Love, the need of renovated iconographies for Christ's representations and the valorization of His childhood.

Searching for related iconography in painting, I have come to a non-traditional representation of Saint Teresa's Transverberation with the two Trinities. In this version, it was the Child Jesus, accompanied by his parents, who pierced the saint's heart, not an angel. As the specialist Fernando Moreno Cuadro (2012: 312) described, this solution gathers the most important subjects for St. Teresa: the Transverber-

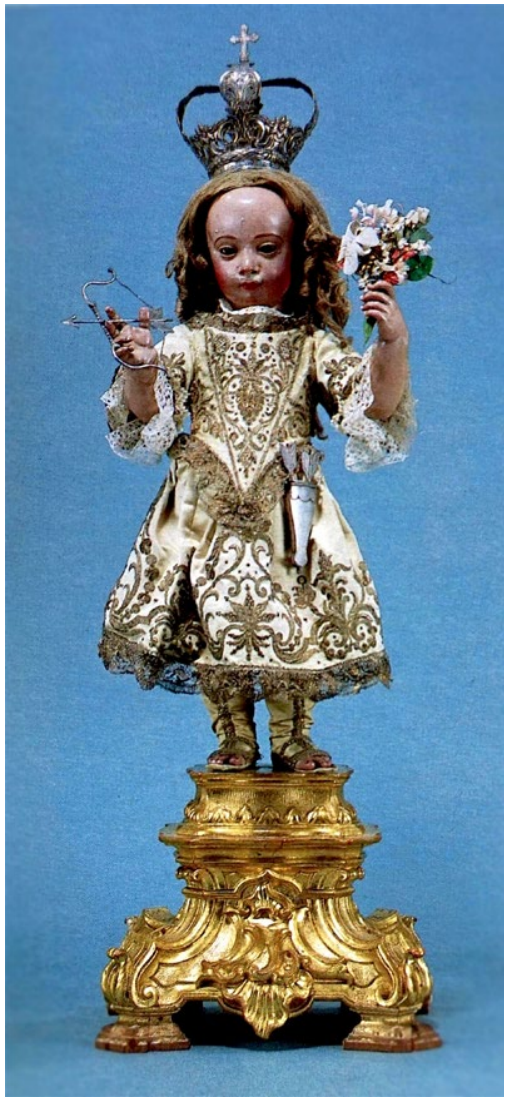

ation, the mystery of the Holy Trinity and the humanity of Christ, represented as a child with his earthly parents.

This iconographic type seems to have been created by the Flemish engraver Antonius II Wierix in 1622 or 1624 (Moreno Cuadro, 2012: 313-322). It followed the trend of publications which instructed and followed the soul's steps (represented as a child) to reach the union with God, through the Divine Love (represented as an angel or putti) ${ }^{2}$. In fact, Wierix himself had published years before the emblem book Cor lesu 


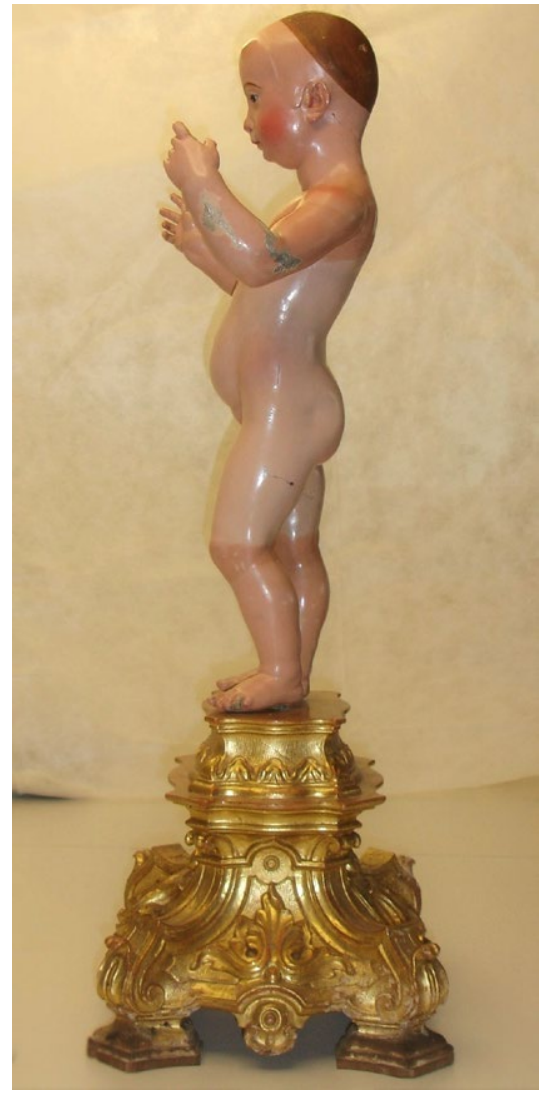

2. The sculpture without clothes. Note the different polychromies in the head and body

Amanti Sacrum, a series around the devout heart where Jesus was also represented as a child (ca. 1586, Antwerp).

Santa Teresa understood the images' value to aid the devotees in their prayer. Through her Life the Saint says how, even young, she «liked to have the Christ's image painted in many places, and an oratory of her own, furnished with objects of devotion» (1904: 55). But she also admits how this was a signal of vanity, and how adorning images was a «trifling act», for it did not represent a significant service to God (1904: 173).

In one of her later Relations she clearly argues in favor of images, acknowledging that «whatever kindled love in me I must not give up, nor take away from my nuns", but firmly rejecting its decorations (Santa Teresa, 1904: 257).

This remark of Santa Teresa is assumed as a reply to the book The Ascent of the Mount Carmel written by San
Juan de la Cruz (1578-1579), in which he argues against the excessive use of images. He is mostly critical against the practice of dressing the saints' sculptures with profane clothing, exposing it as a sign of vanity, devil's conspiracy and idolatry (1922: 344-348).

Despite the criticisms of this two reformers, the dressed sculptures would take an important place in the private and public oratories and their beloved Divine Child would be the main character of this phenomena, alongside with his mother Mary.

According to some authors, the tradition of dressing sacred sculptures started in the private chapels of the royalty and aristocracy, and was later copied by the churches and confraternities (Vega, 1994: 247-248; Webster, 2004: 260-271).

There were also those who blamed women for this practice, like Rodrigo de Moura Telles, Braga's Archbishop between 1704 and 1728, who forbade the use of real clothes in statues to «avoid indecencies that the women's indiscreet devotion profits from» (Maria, 1712: 293-298).

Regarding the images that weren't originally dressed, that might have started as a result of the tradition of offering rich gifts (like textiles and jewels) that gradually started to be displayed in the statues to certify its miraculous power (Genovese, 2009: 21-24). The sculptures specifically created to be dressed, can be a result of the desire to grant them with human characteristics (Cornejo Vega, 1996: 239-240), or an answer to the needs of the liturgical and processional theatre.

Origins aside, this practice had an extensive diffusion. It allowed a much bigger intimacy between the representation of the saint and the believer because of the act of dressing, the act of presenting it with something it would wear, or simply because the real clothing made it look more human.

When looking at the naked and wigless statue of the «Infant Jesus as Divine Love», we clearly see the primal intention of dressing it with textiles because the parts destined to be covered by clothes or hair, have a different color tone [2]

The testimonies of St. Bernard of Clairvaux (1090-1153), St. Francis (1182-1226) and St. Clare (1194-1253) of Assisi, St. Anthony of Padua (1195-1231) or St. Catherine of Siena (1347-1380), among many others, contributed critically to change the rigid and authoritarian medieval image of the Child into a much more affectionate and human one. The childhood 


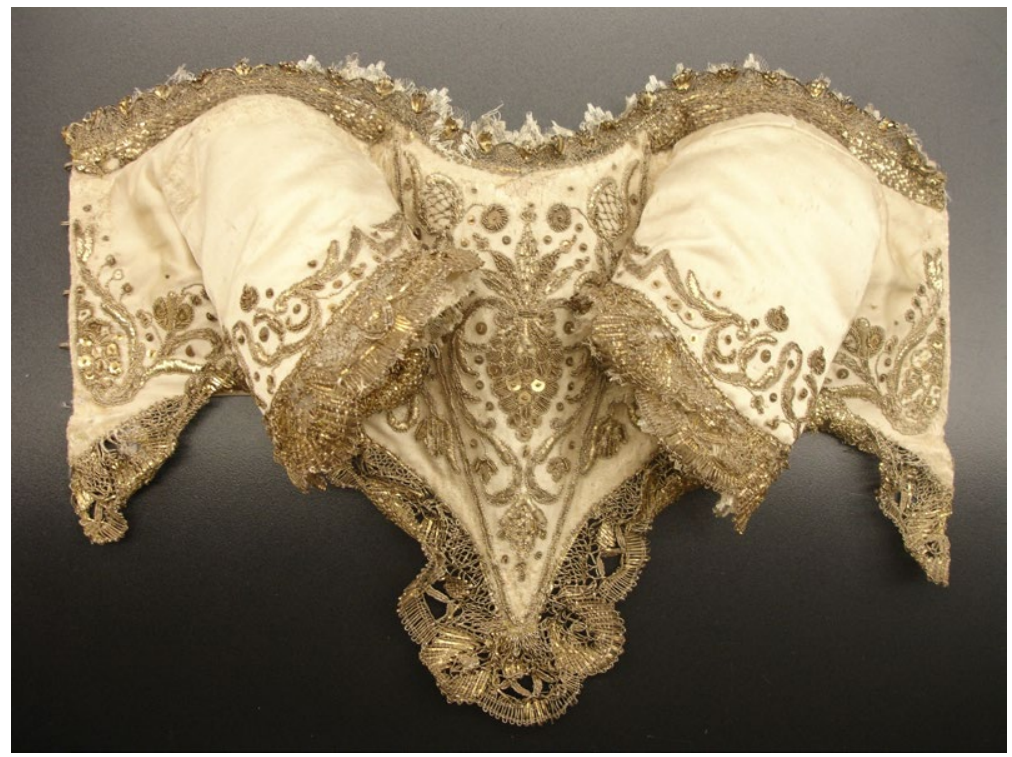

was valued as the token of Christ's humanity, and by the end of the Middle Ages the sculptures of an alone and naked Infant Jesus were already disseminated (Rocca, 2007: 40-43).

Christiane Klapisch-Zuber (1982: 65-75) has shown how common it was, already in the $15^{\text {th }}$ century, for young Florentine women to be given an image of the Infant Jesus together with their trousseau, whether they were to be married or join a convent.

Many authors state the popularity of the Divine Child's sculptures is inherent to the feminine condition, as a replacement of the nun's denied maternity, or as a good luck charm for the fertility of young married women (Silvestrini, 2003: 30; Rocca, 2007: 74).

Soon the Child's images started to be dressed with rich fabrics and brocades (with sets that included detailed lace and linen undergarments) and clothes that followed contemporary fashions, which was common to dressed sculptures of other saints and, especially, of the Virgin Mary. The Infant was usually dressed as a prince, captain or soldier, with a curled wig and a feathered hat, not only with the globe or the cross in his hands, but also a sword (Gonçalves, 1967: 5-34; Fortuna, 1982: 315-332) which would be strongly criticized.

The rich clothing set of our case study, attributed to the $18^{\text {th }}$ century, consists of: a structured bodice, made of cream silk satin, embroidered with gold thread and sequins, and garnished with gold and white lace [3]; skirt and under shorts made of the same materials; sandals made of the same materials, showing the openings to place the statue in the pedestal; an inner shirt of white linen chambray; and lace and white lace cuffs.

The Bishops' Synods tried recurrently to control and forbid the rooted practice of dressing sculptures, requesting decorum and decency, even before Trent's deliberations in 1563 (Martínez-Burgos, 1989: 88-91). But the same advices persisted throughout the $16^{\text {th }}, 17^{\text {th }}$ and $18^{\text {th }}$ centuries, which shows how this practice continued to take place despite the church's bans.

In Portugal, in spite of the legislation forbidding it, this custom was quite popular till late and the sculptures of the Divine Child frequently showed some excesses (Rocha, 1996: 197; Pereira, 2014: 61-66). This fact is stated by friar Agostinho de Santa Maria in his seventh volume of Santuario Mariano, dated from 1721.

In the report regarding his visit to the Franciscan Convent of Our Lady of Jesus in Lisbon, he describes in a rather outraged way how the image of the Infant was adorned «as a soldier, with a sword, a plumed hat, a lace tie and other adornments, rather unrelated from the clothes He actually used, and far from how the images of this humble Lord and peaceful King should be dressed» (Maria, 1721: 111-112). 
Concerning the iconography of Jesus as Divine Love, we know at least two dressed images from Évora, where this dressing phenomena was quite common ${ }^{3}$. Besides the one from Évora's Museum, there is also the «Infant Jesus Divinii Amoris", one of the many representations of the Child from the Poor Clare Convent of St. Helena of the Mount Calvary, attributed to end of the $18^{\text {th }}$ century, which currently belongs the Sacred Art Museum.

It is a wooden sculpture dressed in white satin and linen taffeta. In the chest it bears a silver cartouche with the engraving: "Divinii Amoris». Because it was created to be dressed, the sculpture is not perfectly carved particularly in the area of the shoulders and armpits (Nogueira, 2004: 242).

Regarding this image, it was said «the imagination and lack of solid religious education, combined with influences of classical culture" resulted in the representation of the Infant Jesus as Cupid, bearing the weapons of the mythological pagan god of love (Nogueira, 2004: 244; Gonçalves, 1967: 20).

We can also find non-dressed sculptures of Jesus represented as Divine Love, like the ones in Machado de Castro National Museum ${ }^{4}$ (Coimbra) and National Palace of Ajuda $^{5}$ (Lisbon), both attributed to the $18^{\text {th }}$ century. These fully sculpted images show the clothes carved resembling Roman soldiers. In fact, when facing the previous dressed sculptures, we notice that the satin sandals they both wear may refer to the Roman legionaries' outfit.

This reference can be explained as an obvious mention to Cupid, worshipped as the god of erotic love in Ancient Rome, although his representation was of a naked and winged baby, not a soldier. Another hypothesis is the allusion to the Passion of Christ and the intervention of the roman legionaries. Furthermore, we cannot ignore how common it was to dress the Infant as a soldier or captain, and we are also aware of the strong devotion towards St. Michael, usually depicted with the legionary outfit, but let us not stretch mere assumptions.

Above all, the existence of these fully carved sculptures of the Infant Jesus as Divine Love, show this iconography was not intrinsic to the sculpture dressing phenomenon. Lastly, our case study and other similar ones, cannot be accounted as a result of the extravagant imagination or poor religious education of the nuns. They seem, in fact, to be grounded in the mystical guide books of the Divine Love, which were based in thoughts of prominent theologians like Saint Augustine (354-430). ${ }^{6}$

This peculiar representation of Christ, illustrates the strong contradictions coexisting after the Counter Reformation. While the Church reaffirms the images educational role, it also tries to forbid their excesses. In this context there is a clear fracture between the official norms and the real practices of the believers. Despite the Church's efforts, the image becomes a mirror of vanities both in religious and secular homes.

Finally the dressed image assumes itself as the best means to achieve a closer connection and understanding of Christ's humanity. And the believers' affection is perfectly reflected in the rich sets of clothes and jewels presented devoutly (and excessively) to the Infant Jesus' sculptures.

\section{Notes}

1 En <http://www.matriznet.dgpc.pt/MatrizNet/Objectos/ObjectosConsultar.aspx?ldReg=13825> (fecha de consulta: 10-01-2016). Inv. n ME 1161/1.

2 Like Otto van Veen's Amoris divini emblemata (1615, Antwerp); the Schola cordis siue aversi à deo cordis ac eumdem reductio, et instructio by Benedicto van Haeften and Boëtius à Bolswert (1623, Antwerp); or Pia desideria emblematis, elegiis et affectibus SS. Patrum by Herman Hugo and Boëtius à Bolswert (1624, Antwerp).

3 In Évora, almost every nun had an image of the Infant. During the Easter and Christmas festivities those sculptures would go out in processions through the streets, in a competition to see which one was the most richly decorated and dressed (Nogueira, 2004: 243).

4 En <http://www.matriznet.dgpc.pt/MatrizNet/Objectos/ObjectosConsultar.aspx?ldReg=162398> (fecha de consulta: 10-01-2016). Inv. $n^{\circ}$ 5276; E259.

5 En <http://www.matriznet.dgpc.pt/MatrizNet/Objectos/ObjectosConsultar.aspx?ldReg=1039679> (fecha de consulta: 10-01-2016). Inv. $n^{\circ}$ 51453.

6 According to Arnoud Visser, Van Veen's Amoris divini emblemata has been linked to several mystical traditions, including to St. Teresa's thought, the Jesuit and pietist religiosity and medieval bridal mysticism. But this author places the Augustinian thought in the center of his production (2007: 33-48). 


\section{Bibliography}

CORNEJO VEGA, F. (1996), «La escultura animada en el arte español. Evolución y funciones», Laboratorio de Arte, 9, pp. $239-261$.

FORTUNA, E. (1982), «Imagens Vestidas do Menino Jesus (séculos XVI, XVII e XVIII)», Brigantia, v. II, n. ${ }^{\circ}$ 2/3, pp. $315-332$.

GENOVESE, V. (2009), «Note sulla vestizione delle immagini durante il medievo. Prima Parte», Jacquard Pagine di cultura tessile, 64, pp. 21-24.

GONÇALVES, F. (1967), «O Vestuário Mundano de Algumas Imagens do Menino Jesus», Revista de Etnografia, v. IX, t. 1, Museu de Etnografia e História, Porto, pp. 5-34.

KLAPISCH-ZUBER, C. (1982), "Les Saintes Poupées. Jeu et Dévotion dans la Florence du Quattrocento», Les Jeux à la Renaissance, Actes du XXIlle Colloque International d’Étude Humanistes, Tours 1980, Librarie Philosophique J. Vrin, Paris, pp. 65-79.

MARIA, A. S. (1712), Santuario Mariano, t. IV, Oficina de António P. Galram, Lisboa.

- (1721), Santuario Mariano, t. VII, Oficina de António P. Galram, Lisboa.

MARTÍNEZ-BURGOS GARCíA, P. (1989), «Las constituciones sinodales y la imagen procesional. Normas para la fiesta del siglo XVl», Espacio, Tiempo y Forma, s. VII, t. 2, pp. 81-92.

MORENO CUADRO, F. (2012), «La serie de la Transverberación de santa Teresa con las dos Trinidades derivada de Wierix. Acerca de una pintura de Francisco Rizi», Goya, n. ${ }^{\circ} 341$, pp. 312-323.

NOGUEIRA, S. (2004), «97. Menino Jesus-Divino Amor», en BORGES, A. G. M. (coord.), Tesouros de Arte e Devoção, Fundação Eugénio de Almeida, Évora, pp. 242-244.

PEREIRA, D. (2014), Imagens de Vestir em Aveiro. A Escultura Mariana do século XVII à Contemporaneidade, Tesis de Maestría en Historia del Arte Portuguesa presentada a la Facultad bajo la dirección de Nuno Resende, Porto.

ROCCA, S. (2007), L'Enfant Jésus. Histoire et Anthropologie d'une Dévotion dans l'Occident Chrétien, Presses Universitaires du Mirail, Toulouse.

ROCHA, M. J. M. (1996), «Dirigismo na produção da imaginária religiosa nos séculos XVI-XVIII: as Constituições Sinodais», Museu, s. IV, 5, pp. 187-202.

SAN JUAN DE LA CRUZ (1922), The Ascent of Mount Carmel (trans. David Lewis), Thomas Baker, London.

SANTA TERESA DE JESÚS (1904), The Life of St. Teresa of Jesus, of the Order of Our Lady of Carmel, (trans. David Lewis), Thomas Baker, New York, Benziger Bros, London.

SILVESTRINI, E.; GRI, G.; PAGNOZZATO, R. (2003), Donne Madonne Dee. Abito sacro e riti di vestizione, gioiello votivo, "vestitrici»: un itinerario antropologico in area lagunare veneta, II Poligrafo, Padova.

VEGA, J. (1994), «Irracionalidad popular en el arte figurativo español del siglo XVIIl», Anales de Literatura Española, 10, pp. $237-273$.

VISSER, A. (2007), «Commonplaces of Catholic Love. Otto van Veen, Michel Hoyer and St. Augustine between Humanism and the Counter Reformation", en STRONKS, E.; BOOT, P. (ed.), Learned Love, DANS, The Hague, pp. 33-48.

WEBSTER, S. V. (2004), «Shameless Beauty and Worldly Splendor on the Spanish Practice of Adorning the Virgin», The Miraculous Image in the Late Middle Ages and Renaissance, [s.I], L'erma di Bretschneider, 249-271. 